\title{
Sawdust and digestive bran as cheap alternate substrates for xylanase production
}

\author{
Simphiwe P. Buthelezi, Ademola O. Olaniran* and Balakrishna Pillay \\ Discipline of Microbiology, School of Biochemistry, Genetics and Microbiology, Faculty of Science and Agriculture, \\ University of KwaZulu-Natal (Westville Campus), Private Bag X54001, Durban 4000, Republic of South Africa.
}

Accepted 23 November, 2010

\begin{abstract}
Xylanases are a major group of enzymes, mostly produced from microbial fermentation processes, and have wide industrial and biotechnological applications. The production cost of xylanase is the major factor limiting its use, thus indicating the need for low cost production systems for market of this enzyme. In this study, therefore, sawdust and digestive bran were investigated as substrates for xylanase production by Bacillus strains. The xylanase titre ranging between 30.849 to $45.206 \mathrm{nkat} / \mathrm{ml}$ and 6.633 to $22.717 \mathrm{nkat} / \mathrm{ml}$ was produced by these Bacillus strains, using sawdust and wheat bran as the substrate, respectively. The optimum temperature for the production of xylanase was found to be between 45 and $55^{\circ} \mathrm{C}$, while the optimum pH was 8.0 for all the strains tested. The xylanases produced by these Bacillus strains were found to be stable over a wide range of temperature tested $\left(40\right.$ to $\left.90^{\circ} \mathrm{C}\right)$. Up to 98 and $95 \%$ of the initial activity was retained by the crude extract of two of the Bacillus strains tested, while 10.3 to $56 \%$ loss in activity was observed for the other isolates after one hour incubation at $70^{\circ} \mathrm{C}$. Addition of metal salts or additives to the crude extract was found to inhibit the enzyme activity to a varying degree, with the following order $\mathrm{Hg}^{2+}>\mathrm{EDTA}>\mathrm{Na}>\mathrm{Urea}>\mathrm{Mg}^{2+}>\mathrm{Ca}^{2+}$ observed. Findings from this study indicate the potential use of sawdust and digestive bran as cheaper alternatives for the production of xylanases.
\end{abstract}

Key words: Bacillus sp, digestive bran, sawdust, thermostability, xylanase.

\section{INTRODUCTION}

Organic wastes from agricultural residues comprise cellulose, hemicellulose and lignin in an average ratio of 4:3:3, with hemicellulose being the second most abundant fraction available in nature (Taiz and Honigman, 1976; Abdel-Sater and El-Said, 2001). Xylans, the major portion of the hemicellulose of plant cell walls, are heteropolymers consisting principally of xylose and arabinose (Biely, 1985; Coughlan and Hazlewood, 1993) and is amenable to degradation by different microorganisms, including bacteria, yeasts, and fungi. Several types of enzymes appear to be involved in the degradation of native xylan. Endoxylanases, which attack the linear polyxylose chain in a manner analogous to that of

*Corresponding author. E-mail: olanirana@ukzn.ac.za. Fax: + 2731260 7809. Tel: + 27312607400 . endoglucanase on cellulose, are the most important and have accordingly received the most attention (Sunna and Antranikian, 1997). $\beta$-xylosidase hydrolyzes xylobiose and oligosaccharides to complete the conversion of xylan to xylose and probably relieves the end product inhibition of endoxylanase activity (Srinivasan and Rele, 1999; Subramaniyan and Prema, 2000; Chávez et al., 2006). This activity appears to be extracellular in fungi but cellassociated in bacteria, although relatively few of these enzymes have been studied in detail (Esteghlalian et al., 2008).

Other enzymes play an important role in the removal of side groups from polymeric xylan to create more sites for subsequent enzymatic hydrolysis and possibly contribute to lignin solubilization by attacking the covalent bonds responsible for the integrity of the lignocarbohydrate matrix (Bachmann and McCarthy, 1991; Contreras et al., 2008). The choice of an appropriate substrate is of great 
importance for the successful production of xylanases. The substrate not only serves as carbon and energy source, but also provides the necessary inducing compounds for the organism, preferentially for an extended period of time, for an increased overall productivity of the fermentation process (Duff and Murrayh, 1996; Haltrich et al., 1996). Purified xylans are frequently used for smallscale experiments and are considered as excellent substrates not only because of high yields of xylanase obtained, but also because they cause a selective induction of xylanase with little or no concomitant cellulase activities (Biswas et al., 1990; Gilbert et al., 1992). However the high cost of xylan and other good substrates has limited their applications for larger-scale production processes, hence, the need to search for cheaper alternatives.

Several inexpensive substrates, mainly insoluble lignocellulosic material, such as barley husk, corn cobs, sugarcane bagasse have been used (Camassola and Dillon, 2009). Although poorly investigated, the use of soluble sugars for the production of xylanases has been shown to circumvent problems associated with the use of high concentrations of insoluble substrates, such as media viscosity and difficulties with agitation. In addition, xylose, which can be easily obtained from the xylan portion of lignocellulosic material, has been described as an effective inducer of xylanase activity in several organisms (Haltrich et al., 1996). Biotechnological applications of xylanases have broadened markedly since they are now widely employed as supplements in paper manufacturing, animal feeds, biobleaching of pulp and paper, and in the production of bioethanol (Beg et al., 2000; Subramaniyan and Prema, 2000; Techapun et al., 2003). The most important industrial application of xylanase is in the pre-bleaching of Kraft pulp. This allows for a lower consumption of chemicals during the bleaching process, and also results in a brighter product than can be achieved without the enzymatic treatment (Viikari et al., 1994; Ninawe and Kuhad, 2006). Most of the commercial xylanase is produced by microbial fermentation process.

The production cost of xylanase is the major factor preventing its use, thus indicating the need for low cost production systems for market of this enzyme. Therefore, the main objective of this study is to investigate the potential of cheap raw substrates such as sawdust and digestive bran for the production of xylanases by Bacillus $\mathrm{sp}$. The thermostability and $\mathrm{pH}$ stability of the xylanases produced by these organisms on the raw substrates was also investigated to determine their potential industrial applications.

\section{MATERIALS AND METHODS}

\section{Organisms and sawdust used in this study}

Bacillus strains used in this study, namely; $B$. subtilis (S1), $B$. chitinosporus (S2), B. licheniformis (S3), B. stearothermophilus (S4), B. coagulans (S5), B. uniflagellatus (S6), B. laterosporus (S7), and $B$. pumilus (S8) were obtained from the culture collections of the University of KwaZulu-Natal and Durban University of Technology, South Africa. Pure cultures of the Bacillus strains were preserved on nutrient agar slants and stored at $4^{\circ} \mathrm{C}$. Sawdust used in this study was donated by Country Wood (Pinetown), South Africa and it is composed of Balau deck boards (20\%); Beech wood (20\%); Kiaat (12\%), Mahogany (12\%); SA pine $(5 \%)$; Blackwood (4\%), Cherry (4\%), Meranti (4\%), Saligna (4\%); Cotton wood $(2 \%)$, Cypress (2\%), Imbuia (2\%), Oak (2\%), Rosewood (2\%); Iroko (1\%), Mable hard prime (1\%), Panga Panga (1\%), Spruce $(0.5 \%)$, Tatajuba $(0.5 \%)$, Teak Rhodesian prime $(0.5 \%)$, and Yellow wood (0.5\%).

\section{Preliminary screening for xylanase production}

The bacterial strains were inoculated onto modified xylan agar plates, consisting (in $\mathrm{g} / \mathrm{l}$ ): Digestive bran or sawdust, 10.0; yeast extract, 5.0; peptone, 5.0; $\mathrm{K}_{2} \mathrm{HPO}_{4}, 1.0 ; \mathrm{CaCO}_{3}, 2.0 ;\left(\mathrm{NH}_{4}\right)_{2} \mathrm{SO}_{4}, 2.0$ (pH 8.0) (Kapoor et al., 2008) and 1.8\% (w/v) bacteriological agar. Pure colonies obtained were tested for xylanase production by flooding plates with $0.1 \%$ Congo red for $15 \mathrm{~min}$ and destained with $0.1 \mathrm{M} \mathrm{NaCl}$ for $30 \mathrm{~min}$ (Mamo et al., 2006). The zones of hydrolysis were revealed by finally flooding the plates with $0.5 \%(\mathrm{v} / \mathrm{v})$ acetic acid. Isolates with clearing zone were considered xylanase positive.

\section{Xylanase production and assay}

Erlenmeyer flasks $(250 \mathrm{ml})$ containing $100 \mathrm{ml}$ of modified xylan medium ( $\mathrm{pH} \mathrm{8.0)}$ were inoculated with $5 \mathrm{ml}$ of standardized cultures (OD of 1 at $\left.\lambda_{600 \mathrm{~nm}}\right)$ and incubated at $35^{\circ} \mathrm{C}$ in a rotary shaker (200 rpm) for 4 days. The cultures were harvested by centrifugation at $6000 \times \mathrm{g}$ for $5 \mathrm{~min}$ and the cell free supernatant was then used as an enzyme source. Xylanase activity was measured by the DNS (3,5-dinitrosalicylic acid) assay (Miller, 1959), that determines the amount of reducing sugars liberated from oats-spelt xylan (OSX) (5 $\mathrm{g} / \mathrm{l}$, Sigma) solubilized in phosphate buffer (0.05 M, pH 6.0), according to Bailey et al. (1992). This reaction mixture of an enzyme $(100 \mu \mathrm{l})$ and a substrate $(900 \mu \mathrm{l})$ was incubated for $15 \mathrm{~min}$ at $50^{\circ} \mathrm{C}$, before stopping the reaction by the addition of $1.5 \mathrm{ml}$ DNS solution. The samples were boiled in test tubes for $10 \mathrm{~min}$, cooled under running water for colour stabilization and the optical density was measured at $540 \mathrm{~nm}$. Xylanase activity was determined from a calibration curve constructed with varying concentrations of $D$ xylose (sigma) and expressed in nkat. One nkat (0.0599 IU) was defined as the amount of enzyme that releases $1 \mathrm{nmol} x y l o s e / s$, at $50^{\circ} \mathrm{C}$.

\section{Effect of temperature and $\mathrm{pH}$ on xylanase production}

To determine the optimal conditions for the production of xylanolytic enzymes, $\mathrm{pH}$ of cultivation media (4 to 12) and incubation temperature $\left(30\right.$ to $70^{\circ} \mathrm{C}$ ) were varied and their effect on xylanase production investigated by determining xylanase activities under different conditions as previously described.

\section{Temperature and pH profile of xylanases}

The optimum temperature for the enzyme activity was determined by incubating the crude enzyme at different temperatures ranging from 40 to $90^{\circ} \mathrm{C}$ for $15 \mathrm{~min}$. The $\mathrm{pH}$ profile of crude xylanase was evaluated by incubating the enzyme for $15 \mathrm{~min}$ in the presence of appropriate buffers: $0.05 \mathrm{M}$ citrate buffer $(\mathrm{pH} 4)$; phosphate 


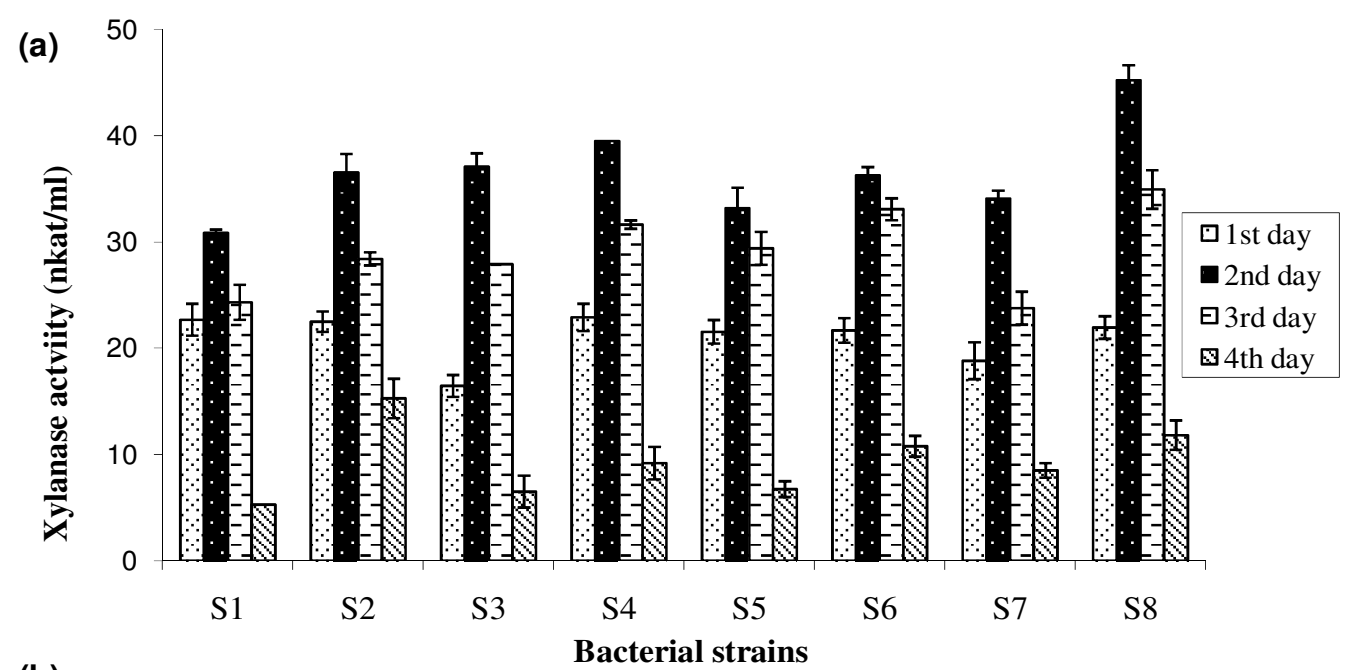

(b)

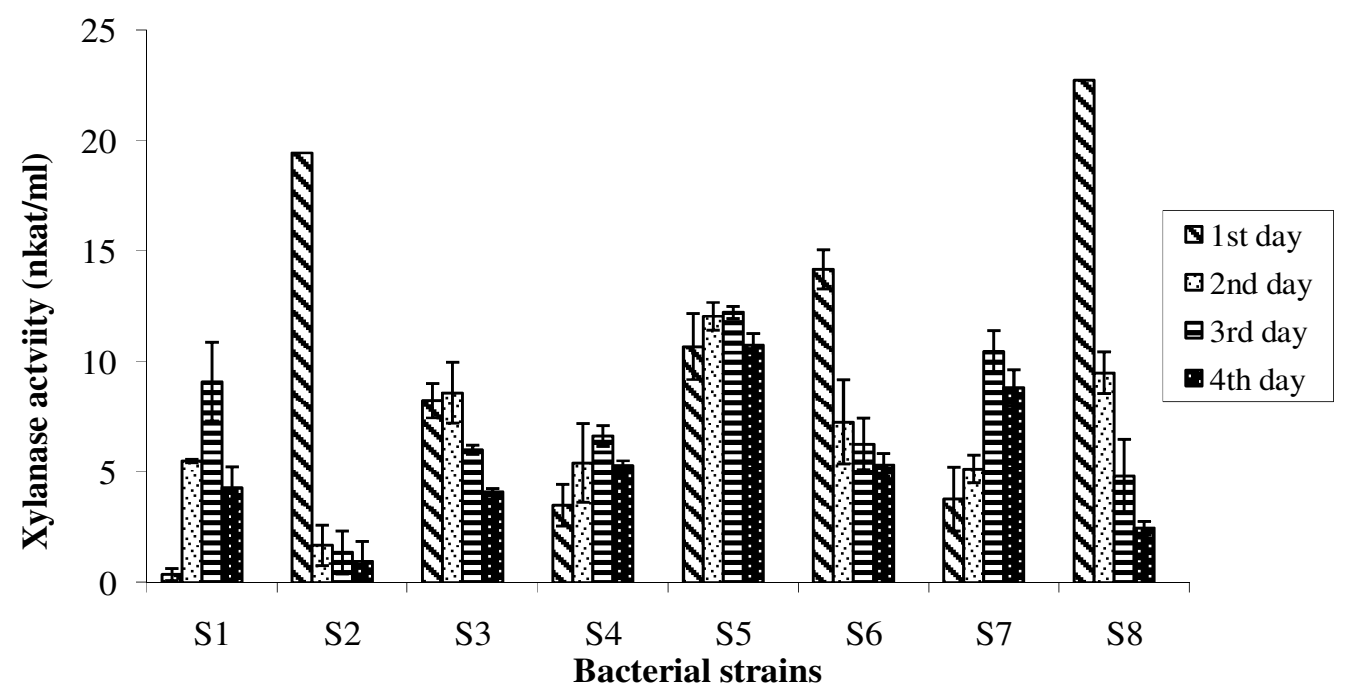

Figure 1. Time-course production of xylanase by the Bacillus strains using (a) sawdust and (b) bran as the substrate.

buffer $(\mathrm{pH} \mathrm{6)}$; Tris- $\mathrm{HCl}$ buffer $(\mathrm{pH}$ 8) and glycine-NaOH $(\mathrm{pH} \mathrm{10)}$ (Sa'-Pereira et al., 2002; Anuradha et al., 2007) at the predetermined temperature.

Xylanase activity was determined by using the DNS assay as previously described.

\section{The effect of metal salts or additives on xylanase activity}

The effect of metal salts or additives was determined by incubating the crude enzyme $(100 \mu \mathrm{l})$ with $10 \mu \mathrm{l}$ of $0.1 \mathrm{M}$ salt solution $\left(\mathrm{MgCl}_{2}\right.$, $\mathrm{HgCl}_{2}, \mathrm{EDTA}, \mathrm{NaCl}, \mathrm{CaCl}_{2}$, and Urea) (Bataillon et al., 2000) before measuring xylanase activity.

\section{Thermostability and pH stability of xylanases}

Temperature stability studies were performed by incubating the crude enzyme at an optimum $\mathrm{pH}$ of 6 and at temperatures ranging from 40 to $90^{\circ} \mathrm{C}$ for 1 to $4 \mathrm{~h}$ (Sa'-Pereira et al., 2002; Anuradha et al., 2007). The pH stability was determined by incubating the crude enzyme in appropriate buffers:

Citrate buffer $(\mathrm{pH} \mathrm{4)}$; phosphate buffer $(\mathrm{pH} 6.0$ and 7.0); Tris- $\mathrm{HCl}$ buffer, $[\mathrm{pH} 8.0]$, and glycine- $\mathrm{NaOH},(\mathrm{pH} 10$ and 12) (Anuradha et al., 2007).

Xylanase activity was determined every hour using DNS assay as previously described and the relative activity of the enzyme determined by comparing activity at time $(\mathrm{t})$ to the initial activity obtained before incubation.

\section{RESULTS}

\section{Xylanase production on digestive bran and sawdust}

The xylanase production profile of the Bacillus strains using digestive bran and sawdust as substrate over a 4 
day period is shown in Figure 1. The xylanase activity of the crude enzymes obtained from the Bacillus strains grown on sawdust was optima after 2 day and ranged between 30.849 to $45.206 \mathrm{nkat} / \mathrm{ml}$ (Figure 1a), while the activity peaked between days 1 and 3 for the different strains when digestive bran was used as a substrate and ranged between 6.633 to $22.717 \mathrm{nkat} / \mathrm{ml}$ (Figure 1b). Sawdust was observed to be a better substrate, resulting in higher amount of xylanase production by all the bacterial strains, compared to the digestive bran. Bacillus strain S8 was found to produce the highest amount of xylanase, irrespective of the substrate used.

\section{Effect of temperature and $\mathrm{pH}$ on the production of xylanases}

The effects of temperature and $\mathrm{pH}$ on the hydrolysis of oat-spelt xylan by the crude xylanase produced by these Bacillus strains were evaluated, in order to determine the optimum conditions. The optimum temperature for the production of xylanase was found to be observed by $55^{\circ} \mathrm{C}$ for the strains, except for isolates S2 and S5 where the optimum temperature was $45^{\circ} \mathrm{C}$ (Figure 2a). A decrease in xylanase production was observed above and below these optima. In all the strains, the optimum $\mathrm{pH}$ for the production of xylanases were $\mathrm{pH} 8$ (Figure $2 \mathrm{~b}$ ). However, a slight increase in xylanase production was noted at $\mathrm{pH} 12$ for isolates S1-S6, compared to $\mathrm{pH} 10$.

\section{Determination of the temperature and $\mathrm{pH}$ profile of xylanases on sawdust}

The highest activity was obtained when the enzyme was incubated at $50^{\circ} \mathrm{C}$, while increase in temperature from 60 to $90^{\circ} \mathrm{C}$ tend to strongly inhibit the enzyme activity, with up to 6 -fold decrease in activity observed from 50 to $70^{\circ} \mathrm{C}$ (Figure 3a). The optimum $\mathrm{pH}$ for xylanase activity was achieved at $\mathrm{pH} \mathrm{6}$, with 1.37 to 14 fold increase in activity observed at $\mathrm{pH} 10$, compared to those at $\mathrm{pH} 8$ for all the tested organisms (Figure 3b).

\section{The thermostability and pH stability of xylanases}

The xylanases produced by these Bacillus strains were found to be stable over a wide range of temperature tested $\left(40\right.$ to $\left.90^{\circ} \mathrm{C}\right)$. However, results presented in this paper are for the thermostability of the crude enzyme at 70 and $90^{\circ} \mathrm{C}$. It is worth noting that xylanases produced by strain $\mathrm{S} 1$ and $\mathrm{S} 6$ retained up to 98 and $95 \%$ of the initial activity, respectively, with between 10.3 and $56 \%$ loss in activity observed for the other isolates after one hour incubation at $70^{\circ} \mathrm{C}$ (Figure 4a). Up to 25.80 to $60.61 \%$ activity was still retained by the crude enzyme extract of the strains, even after $3 \mathrm{~h}$. At $90^{\circ} \mathrm{C}$, the enzyme retained between 45 to $80 \%$ of its activity after one hour, after which a progressive decrease in activity was observed as the incubation time increases, with 86.05 to $98.68 \%$ loss in activity observed after $4 \mathrm{~h}$ (Figure 4b). The $\mathrm{pH}$ stability of xylanases produced by Bacillus strains was determined at $\mathrm{pH} 4 ; 6$; 8 ; and 12 by using appropriate buffers. However only results for $\mathrm{pH} 6$ to 10 are shown in this article.

Xylanases were less stable at $\mathrm{pH} 4$ and lost most of its activity after $1 \mathrm{~h}$. At pH 6, the enzyme was more stable for $2 \mathrm{~h}$, with isolates S5 and S9 losing only $19 \%$ and $16 \%$ of its activity respectively after $1 \mathrm{~h}$ (Figure $5 \mathrm{a}$ ). At pHs 8 , 10 and 12, a drastic decrease in enzyme activity was observed after $2 \mathrm{~h}$ (Figures $5 \mathrm{~b}$, c, and d), with most of the enzyme activity lost after $4 \mathrm{~h}$ (Figure $5 \mathrm{~d}$ ). However, xylanases produced by isolate $\mathrm{S} 3$ retained $73 ; 80$ and $77 \%$ of its activity at $\mathrm{pH} 8,10$ and 12 , respectively.

\section{Effects of metal salts or additives on xylanase activity}

Addition of metal salts or additives to the crude extract was found to inhibit the enzyme activity to a varying degree (Table 1). Generally, $\mathrm{HgCl}$ and EDTA were found to have the most negative effect on the enzyme activity, with up to 90.34 and $94.32 \%$ reduction in activity, respectively, observed for the crude extract of strain S4. $\mathrm{CaCl}_{2}$ and $\mathrm{MgCl}_{2}$ only slightly inhibited the enzyme activity, with up to 96 and $87 \%$, respectively, of the activity retained. The general pattern of enzyme inhibition follows the order of $\mathrm{Hg}^{2+}>\mathrm{EDTA}>\mathrm{Na}>\mathrm{Urea}>\mathrm{Mg}^{2+}>$ $\mathrm{Ca}^{2+}$.

\section{DISCUSSION}

The production cost of xylanase is the major factor preventing their use, thus indicating the need for low cost production systems for this enzyme (Bae et al., 2008). Various substrates including, larchwood, beechwood, birchwood, wheat bran, oat-spelt, corn cob, sugar beet pulp, sugarcane bagasse, and various industrial wastes have been used for their production (Bailey et al., 1992; Maheshwari et al., 2000). In this study, digestive bran and sawdust were used as cheap alternate substrates for the production of xylanase by Bacillus strains. Sawdust is a material that exhibits a high polarity mainly due to the presence of different oxygen-containing functional groups such as alcohol and ether (Bledzki and Gassan, 1999; Álvarez et al., 2005). The cell walls of sawdust mainly consist of cellulose and lignin, and many hydroxyl groups, such as tannins or other phenolic compounds, which are active ion exchange compounds. The lignin content of hardwoods is usually in the range of 18 to $25 \%$, whereas that of softwoods varies between 25 and 35\% (Batzias and Sidiras, 2007). 
(a)

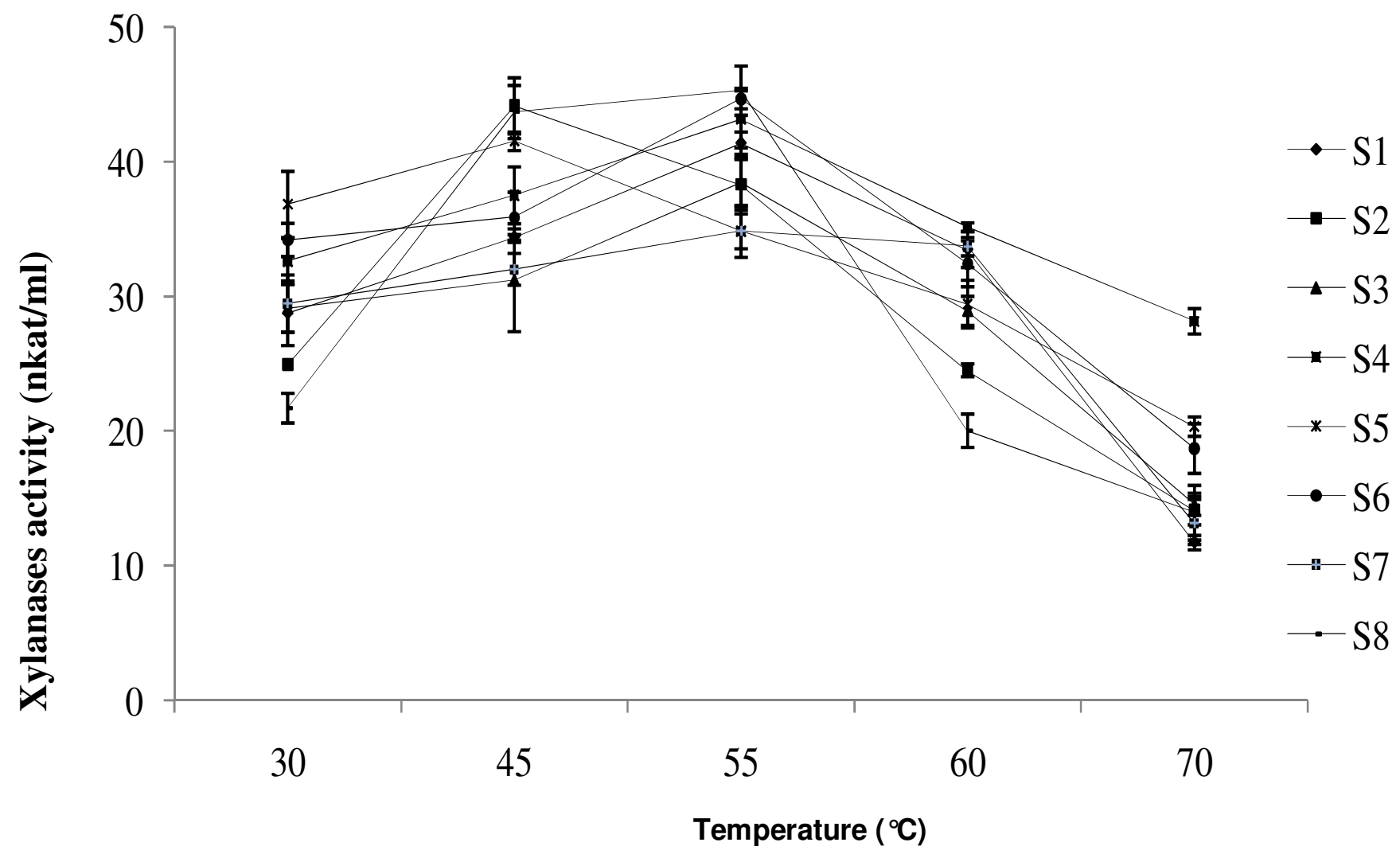

(b)

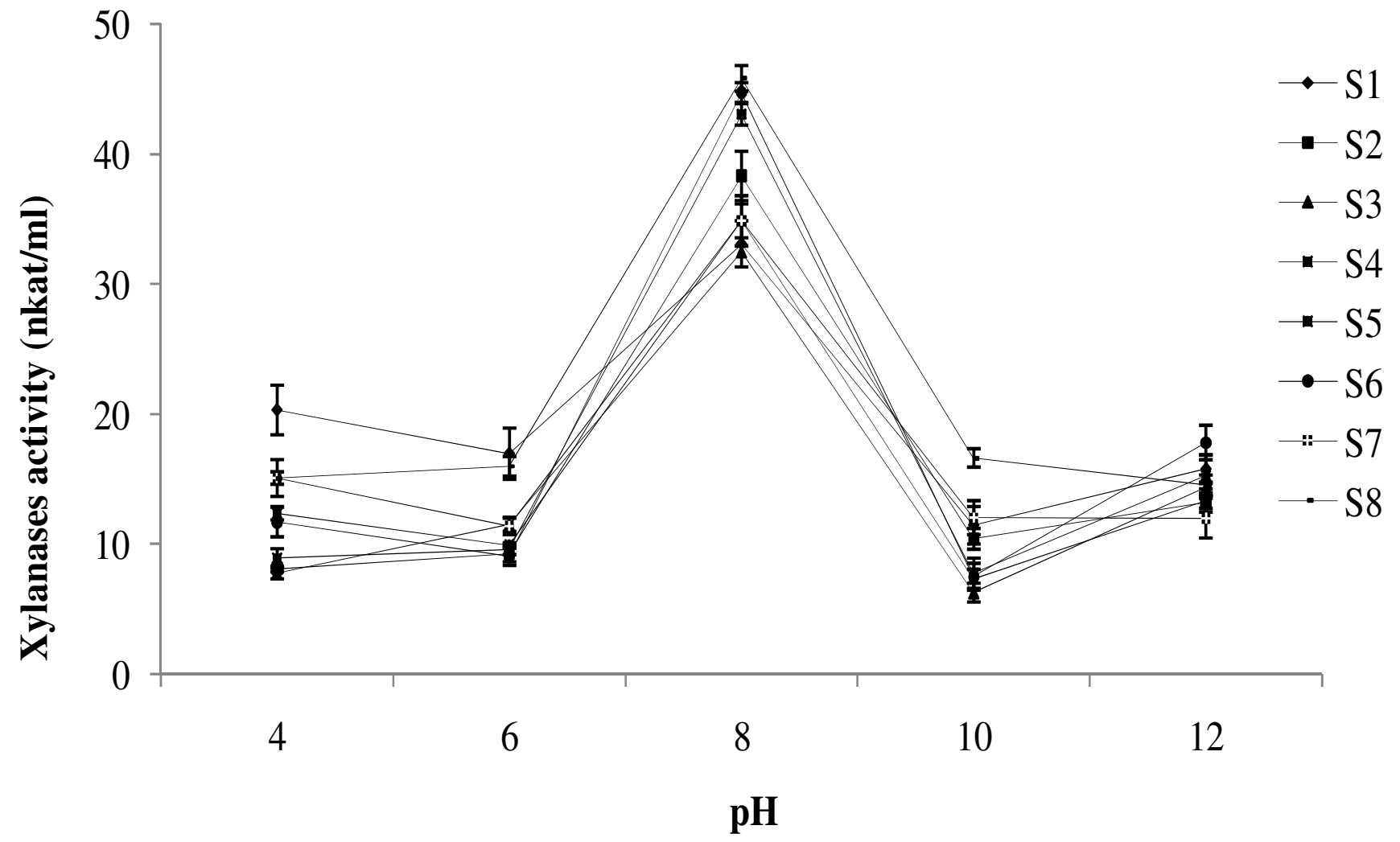

Figure 2. The effect of (a) temperature and (b) pH on the production of xylanase using sawdust as the substrate. 
(a)

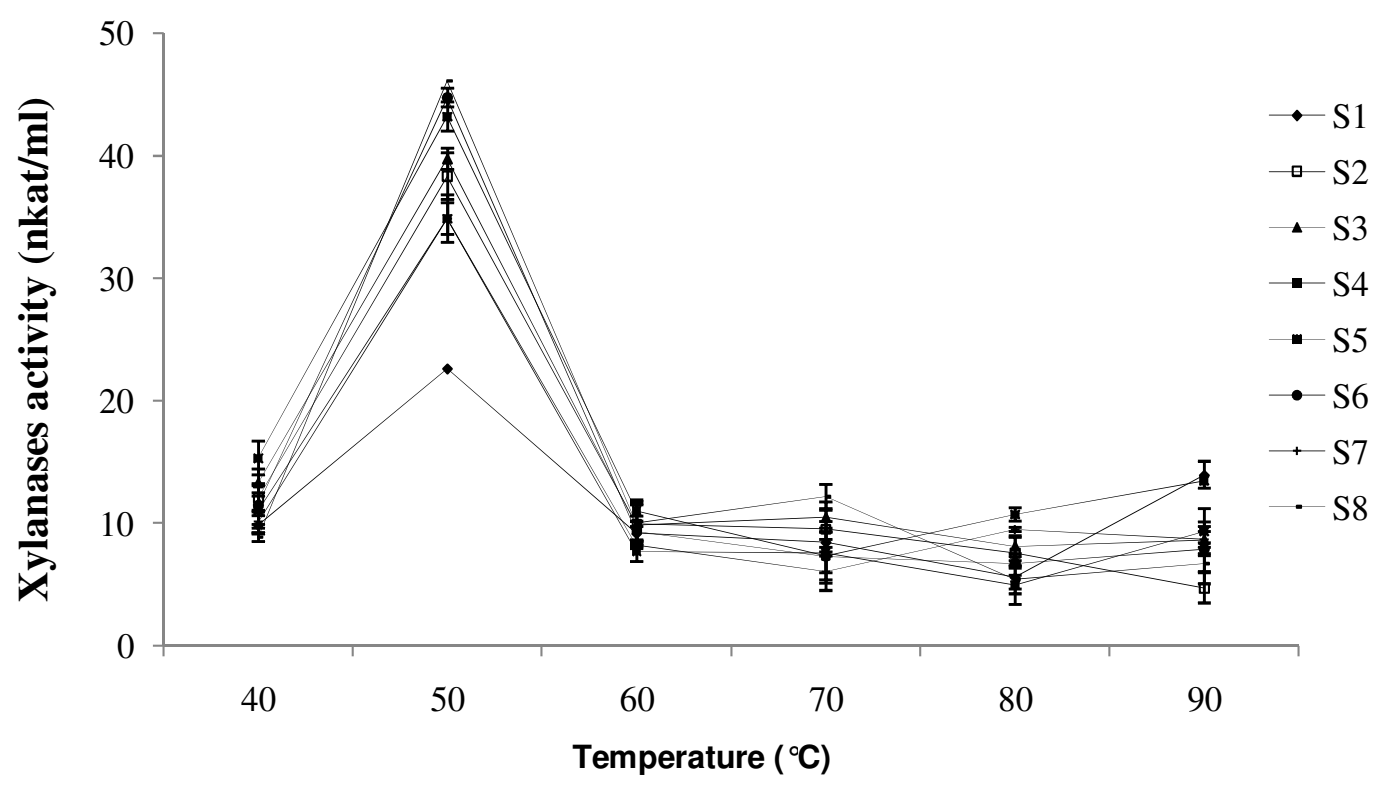

(b)

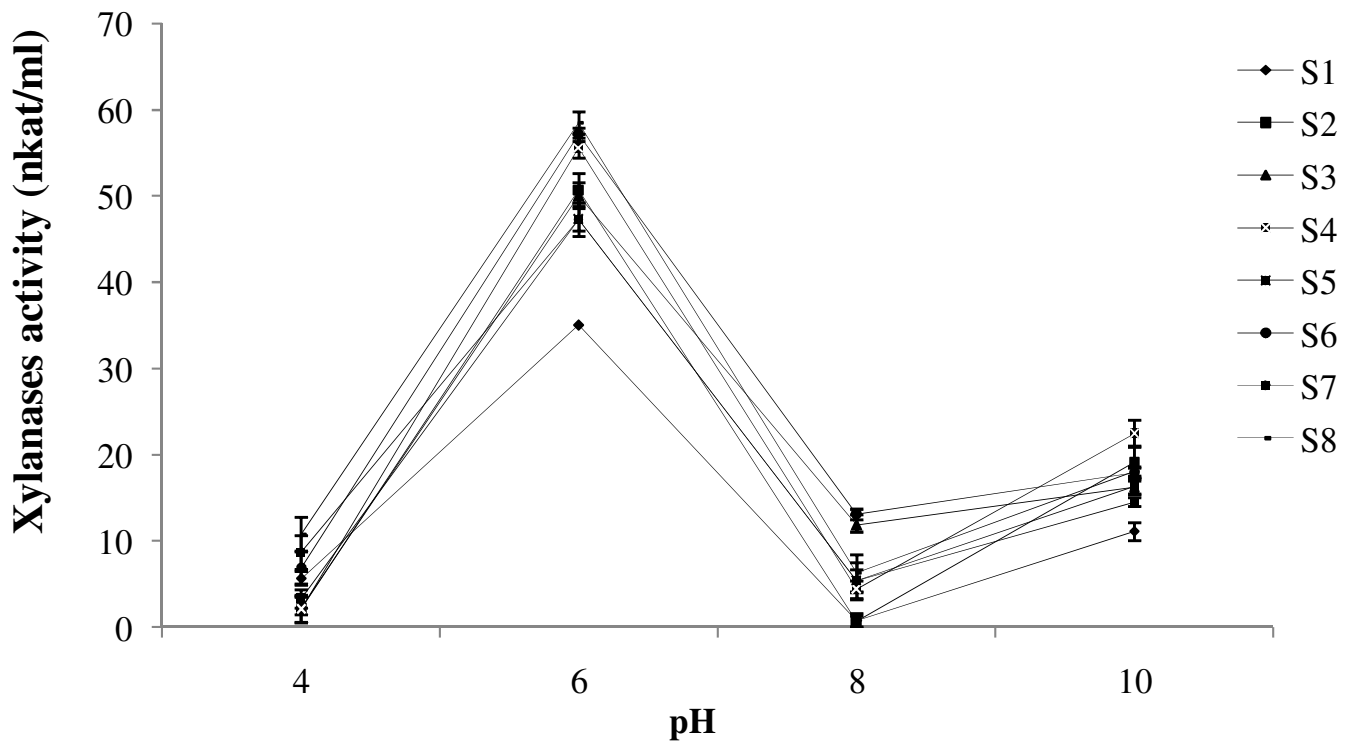

Figure 3. The effect of (a) temperature and (b) pH on xylanase activity of the crude enzyme produced by the Bacillus strains on sawdust.

Sawdust used in the present study had high beech wood $(20 \%)$ content making it an ideal substrate for xylanase production, since beechwood has been reported as a good substrate for xylanase production (Bailey et al., 1992; Maheshwari et al., 2000). The composition of the sawdust is indicated under materials and methods. This could explain the high xylanase production on sawdust by all the isolates used in this study. The decrease in enzyme activity observed after the second day of incubation could possibly be due to the accumulation of metabolic waste and production of proteases which might inhibit xylanase activity (Gessesse and Mamo, 1999). Nawel et al. (2010) reported that Jonesia denitrificans $\mathrm{BN}-13$ isolated from Algerian soil produced extracellular 
(a)

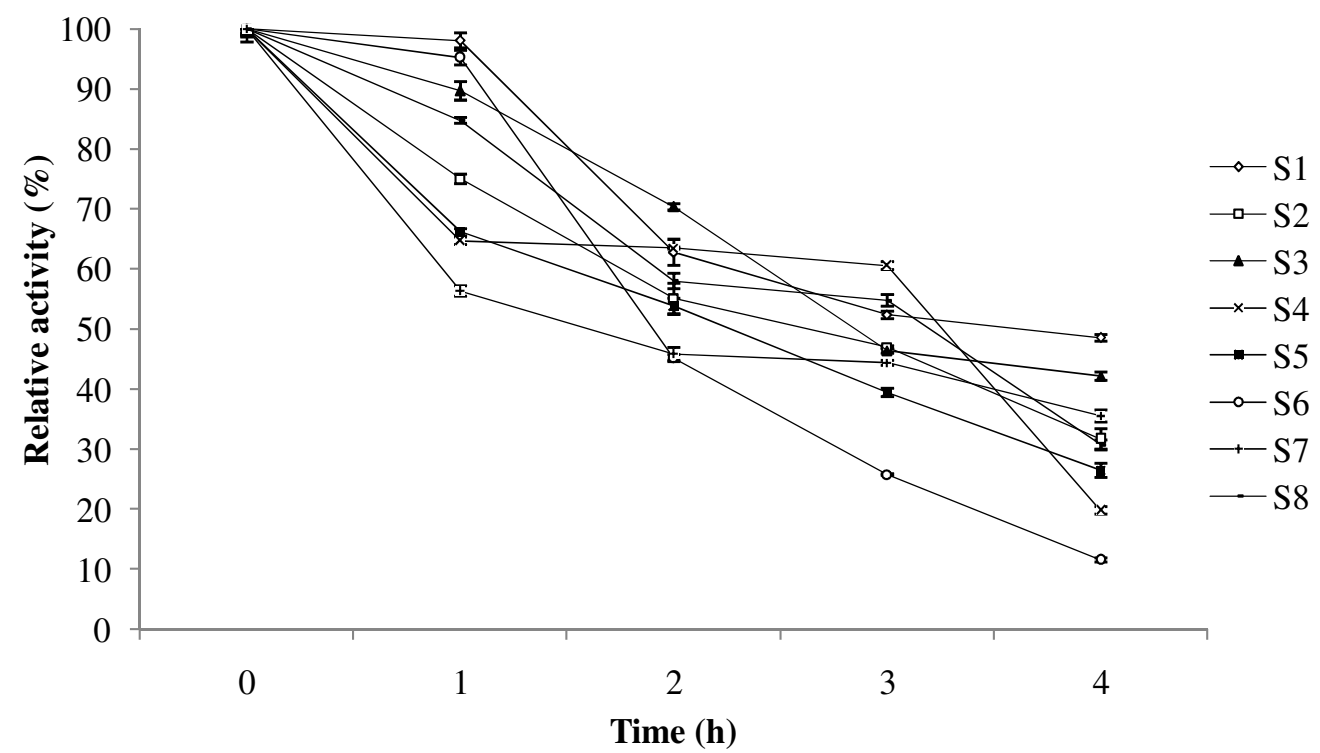

(b)

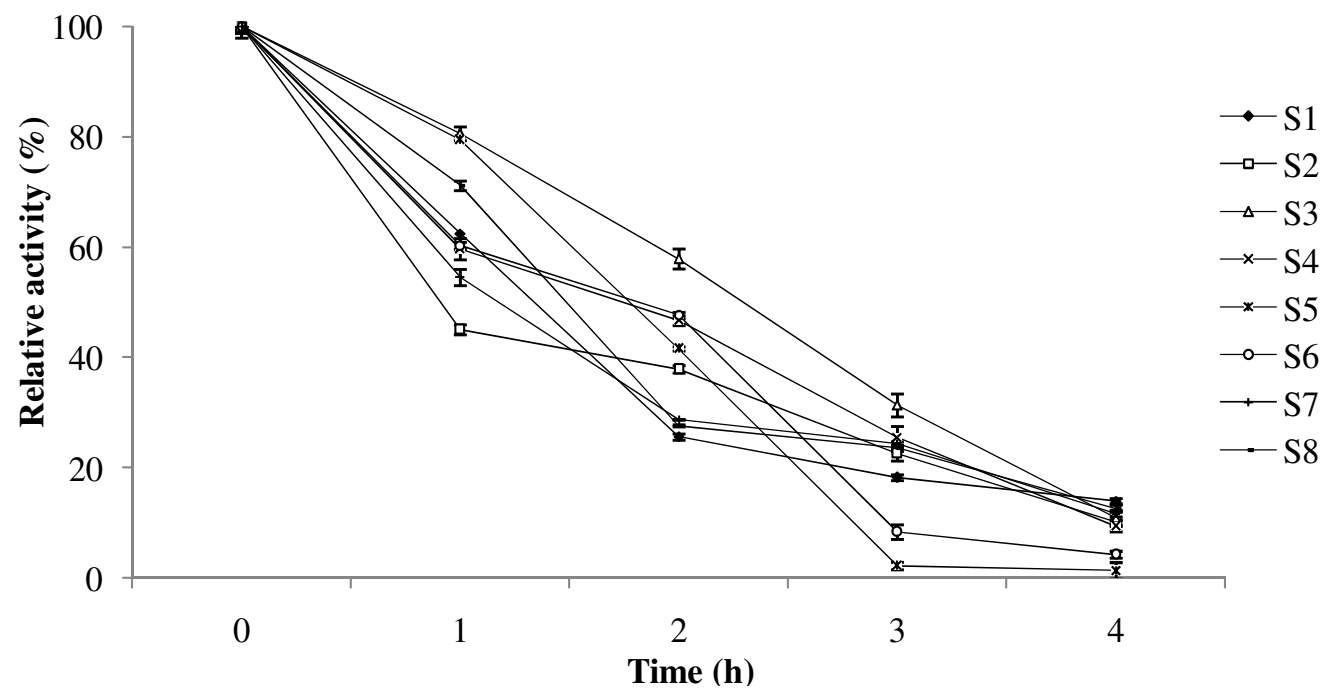

Figure 4. The thermostability of crude xylanase at (a) $70^{\circ} \mathrm{C}$ and (b) $90^{\circ} \mathrm{C}$ using sawdust as the substrate.

xylanases, and that the best xylanolytic activity was obtained using birchwood xylan $(7 \mathrm{mg} / \mathrm{ml})$, yeast extract $(2.5 \mathrm{mg} / \mathrm{ml}), \mathrm{NaCl}(3 \mathrm{mg} / \mathrm{ml}), \mathrm{NH}_{4} \mathrm{Cl}(6 \mathrm{mg} / \mathrm{ml})$, and $\mathrm{MgSO}_{4}(0.3 \mathrm{mg} / \mathrm{ml})$. Bacteria belonging to the genus Bacillus have been widely used for the production of hemicellulase and xylanases (Coughlan and Hazlewood, 1993; Pinaga et al., 1993), with variation in the production efficiency and thermostability of the enzymes produced (Ramesh and Lonsame, 1989; Asther and Meunier, 1990).

Pham et al. (1999) observed that up to $24 \mathrm{nkat} / \mathrm{ml}$ of xylanase was produced on lignocellulosic wastes within 36 and $42 \mathrm{~h}$ at $30^{\circ} \mathrm{C}$ using Bacillus polymyxa. This is much lower than the highest titre produced by isolates S2 (36.528 $\mathrm{nkat} / \mathrm{ml}), \quad$ S3 $(37.074 \mathrm{nkat} / \mathrm{ml}), \quad$ S4 $(39.482$ nkat $/ \mathrm{ml})$, S6 (33.075 nkat $/ \mathrm{ml})$, and S8 (45.206 nkat $/ \mathrm{ml})$ on sawdust in this study. Similarly, a high level of xylanase production by Bacillus sp. AR-009 has been observed when wheat bran was used as a solid support; with maximum enzyme production observed after $72 \mathrm{~h}$ (Gessesse and Mamo, 1998). Further incubation after this time did not show any improvement in the level of enzyme production, which is comparable to the findings of the present study. However, higher xylanase production of up to $1455 \mathrm{U}$ xylanase/g deoiled seed cake 
(a)

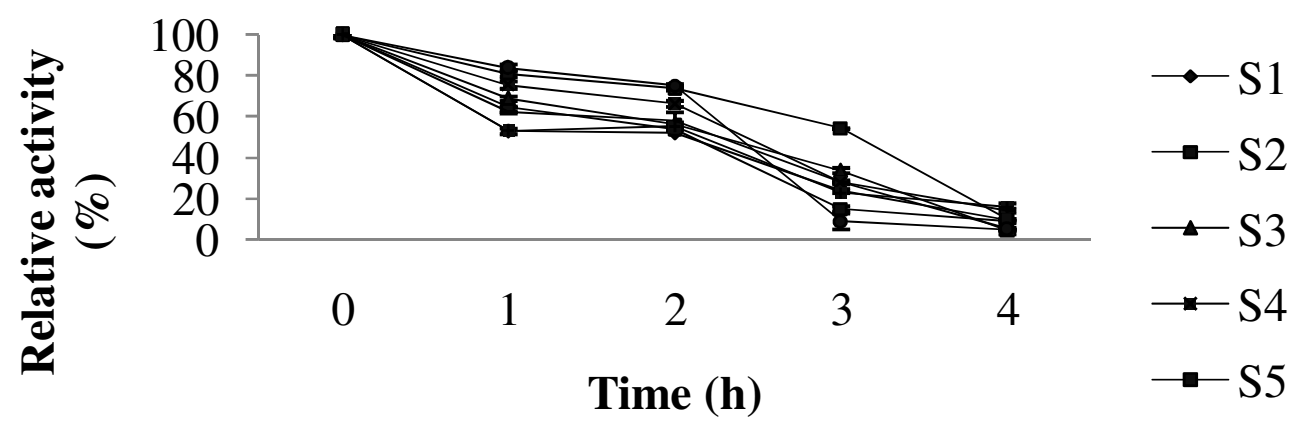

(b)

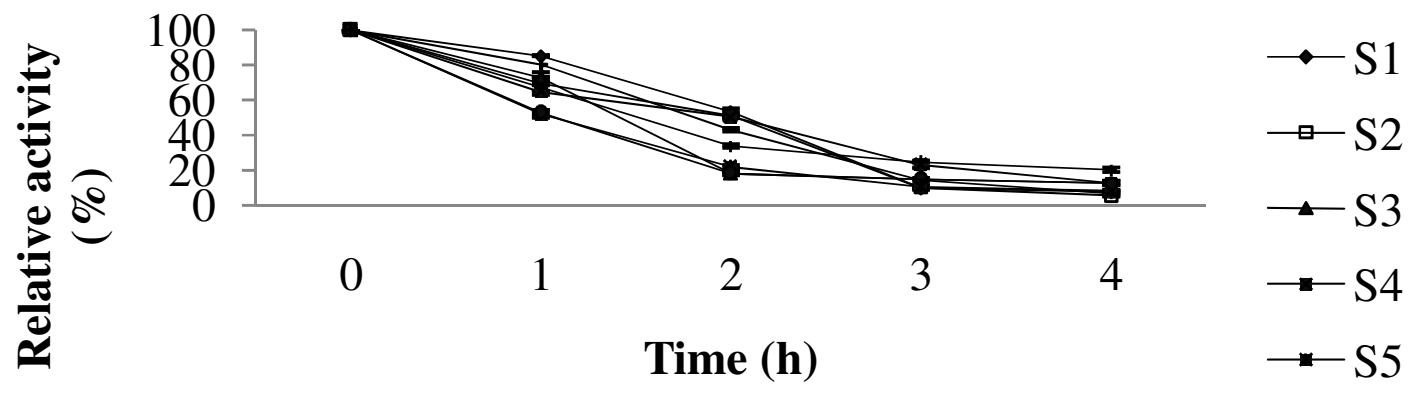

(c)

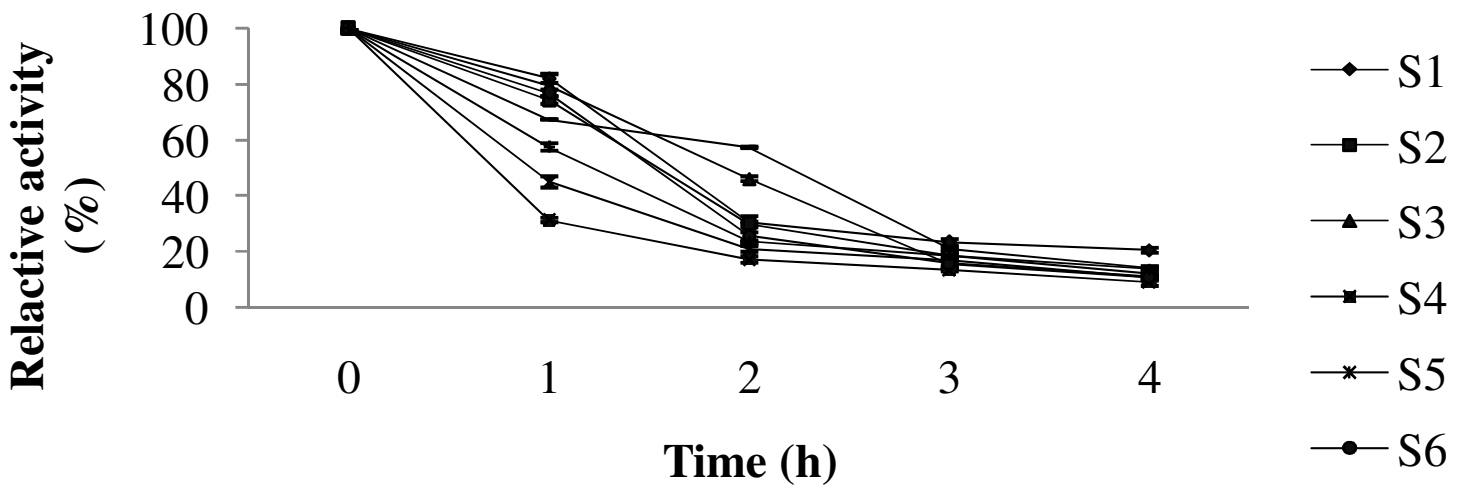

(d)

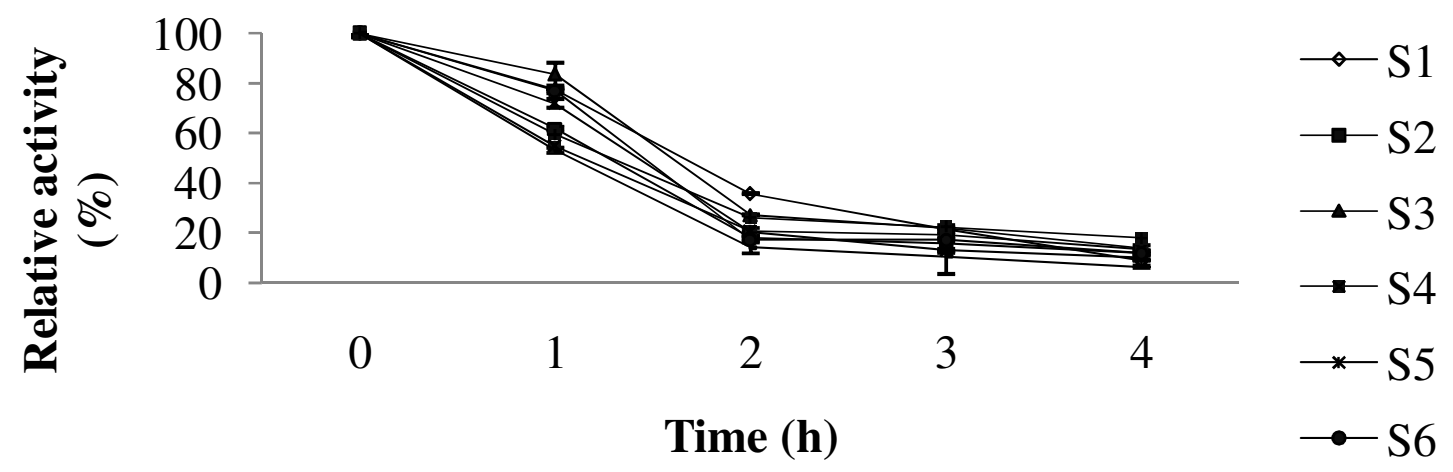

Figure 5. The stability of crude xylanases at (a) pH 6 (b) pH 8 (c) pH 10 and (d) pH 12 using sawdust as the substrate. 
Table 1. Effects of metal salts or additives on xylanase activity.

\begin{tabular}{|c|c|c|c|c|c|c|c|}
\hline \multirow[b]{2}{*}{ Isolates } & \multicolumn{7}{|c|}{ Xylanase activity (nkat/ml) } \\
\hline & None & $\mathrm{MgCl}_{2}$ & $\mathrm{HgCl}_{2}$ & EDTA & $\mathrm{NaCl}$ & $\mathrm{CaCl}_{2}$ & Urea \\
\hline S1 & $\begin{array}{c}30.197 \pm 1.307 \\
(100)\end{array}$ & $\begin{array}{c}6.256 \pm 0.849 \\
(22.186)\end{array}$ & $\begin{array}{c}3.491 \pm 0.797 \\
(11.560)\end{array}$ & $\begin{array}{c}7.888 \pm 1.178 \\
(26.122)\end{array}$ & $\begin{array}{c}6.301 \pm 1.846 \\
(20.866)\end{array}$ & $\begin{array}{c}18.995 \pm 2.993 \\
(62.904)\end{array}$ & $\begin{array}{c}6.437 \pm 0.685 \\
(21.317)\end{array}$ \\
\hline S2 & $\begin{array}{c}33.256 \pm 2.159 \\
(100)\end{array}$ & $\begin{array}{c}14.779 \pm 0.490 \\
(44.440)\end{array}$ & $\begin{array}{c}4.035 \pm 4.215 \\
(12.133)\end{array}$ & $\begin{array}{c}2.312 \pm 0.283 \\
(6.952)\end{array}$ & $\begin{array}{c}6.528 \pm 0.471 \\
(19.629)\end{array}$ & $\begin{array}{c}10.381 \pm 2.468 \\
(31.215)\end{array}$ & $\begin{array}{c}7.117 \pm 2.117 \\
(21.401)\end{array}$ \\
\hline S3 & $\begin{array}{c}35.091 \pm 1.498 \\
(100)\end{array}$ & $\begin{array}{c}4.715 \pm 1.919 \\
(13.436)\end{array}$ & $\begin{array}{c}10.291 \pm 2.277 \\
(29.327)\end{array}$ & $\begin{array}{c}4.035 \pm 0.566 \\
(11.499)\end{array}$ & $\begin{array}{c}4.352 \pm 2.404 \\
(12.402)\end{array}$ & $\begin{array}{c}12.784 \pm 2.247 \\
(36.431)\end{array}$ & $\begin{array}{c}5.077 \pm 1.108 \\
\quad(14.468)\end{array}$ \\
\hline S4 & $\begin{array}{c}39.536 \pm 0.906 \\
(100)\end{array}$ & $\begin{array}{c}7.344 \pm 1.173 \\
(18.575)\end{array}$ & $\begin{array}{c}3.627 \pm 1.836 \\
(9.174)\end{array}$ & $\begin{array}{c}2.131 \pm 1.157 \\
(5.421)\end{array}$ & $\begin{array}{c}6.891 \pm 0.965 \\
(17.430)\end{array}$ & $\begin{array}{c}10.109 \pm 1.516 \\
(25.569)\end{array}$ & $\begin{array}{c}7.117 \pm 2.452 \\
(20.028)\end{array}$ \\
\hline S5 & $\begin{array}{c}32.749 \pm 1.157 \\
(100)\end{array}$ & $\begin{array}{c}22.349 \pm 0.157 \\
(68.243)\end{array}$ & $\begin{array}{c}10.200 \pm 2.211 \\
(31.146)\end{array}$ & $\begin{array}{c}9.701 \pm 2.589 \\
(29.622)\end{array}$ & $\begin{array}{c}14.235 \pm 0.192 \\
(43.467)\end{array}$ & $\begin{array}{c}21.397 \pm 2.867 \\
(65.336)\end{array}$ & $\begin{array}{c}15.867 \pm 3.012 \\
(48.450)\end{array}$ \\
\hline S6 & $\begin{array}{c}36.099 \pm 1.886 \\
(100)\end{array}$ & $\begin{array}{c}20.717 \pm 2.631 \\
\quad(57.389)\end{array}$ & $\begin{array}{c}4.669 \pm 1.439 \\
(12.934)\end{array}$ & $\begin{array}{c}9.157 \pm 1.529 \\
(25.366)\end{array}$ & $\begin{array}{c}5.712 \pm 2.879 \\
\quad(15.823)\end{array}$ & $\begin{array}{c}29.875 \pm 2.211 \\
(82.759)\end{array}$ & $\begin{array}{c}17.816 \pm 0.593 \\
(49.353)\end{array}$ \\
\hline S7 & $\begin{array}{c}32.976 \pm 1.539 \\
(100)\end{array}$ & $\begin{array}{c}5.485 \pm 1.662 \\
(16.633)\end{array}$ & $\begin{array}{c}4.941 \pm 2.186 \\
(14.984)\end{array}$ & $\begin{array}{c}6.075 \pm 0.749 \\
\quad(18.422)\end{array}$ & $\begin{array}{c}2.765 \pm 0.136 \\
(8.385)\end{array}$ & $\begin{array}{c}15.051 \pm 1.935 \\
(45.642)\end{array}$ & $\begin{array}{c}5.848 \pm 1.021 \\
(17.734)\end{array}$ \\
\hline S8 & $\begin{array}{c}43.744 \pm 1.778 \\
(100)\end{array}$ & $\begin{array}{c}23.936 \pm 2.345 \\
(54.718)\end{array}$ & $\begin{array}{c}9.429 \pm 2.406 \\
(21.554)\end{array}$ & $\begin{array}{c}5.259 \pm 0.757 \\
(12.022) \\
\end{array}$ & $\begin{array}{c}20.173 \pm 4.491 \\
(46.116)\end{array}$ & $\begin{array}{c}25.296 \pm 1.533 \\
(57.827)\end{array}$ & $\begin{array}{c}11.243 \pm 1.623 \\
(25.701)\end{array}$ \\
\hline
\end{tabular}

Results are average of triplicate data \pm standard deviation while values in parenthesis represent the percentage relative activity.

has been reported for the thermophilic fungus Scytalidium thermophilum by solid-state fermentation when Jatropha curcas seed cake was used as a substrate under optimized conditions (Joshi and Khare, 2010).

Temperature plays a crucial role in enzyme production and activity. The temperature and the $\mathrm{pH}$ optima of the bacterial or fungal enzymes often reflect the $\mathrm{pH}$ and temperature of its habitat. The highest enzyme production was observed between 45 and $55^{\circ} \mathrm{C}$ (Figure 2a), while the highest enzyme activity was obtained at $50^{\circ} \mathrm{C}$

(Figure 3a), which was slightly lower than $60^{\circ} \mathrm{C}$ reported by Sá-Pereira et al. (2002) and Liu and Liu (2008). Hidayah et al. (2008) showed that endoglucanase from $B$. pumilus EB3 was maximally secreted at $37^{\circ} \mathrm{C}$ at the initial $\mathrm{pH}$ of 7 which is in contrast to the observation of this study. A decrease in activity was observed at high temperatures of 60 and $70^{\circ} \mathrm{C}$. Enzymes have temperature optima for maximum activity, and a rise in temperature above this optimum could results in disruption of enzyme structure and subsequent loss in activity (Prescott et al., 1996). Bataillon et al. (2000) showed that xylanase from Bacillus sp were most active at $75^{\circ} \mathrm{C}$ and also stable at $\mathrm{pH}$ of 7 to 9 , which is comparable to those of the current study as the optimum $\mathrm{pH}$ for xylanase production was at $\mathrm{pH} 8$.

A further increase in enzyme production at $\mathrm{pH}$ 
12 (Figure $2 \mathrm{~b}$ ) and activity at $\mathrm{pH} 10$ (Figure 3b) could be attributed to the production of multiple xylanases, which has also been previously reported (Wong et al., 1988; Gessesse, 1998; Cacais et al., 2001). Battan et al. (2007) reported a peak xylanase production by Bacillus pumulis when grown in medium at $\mathrm{pH}$ 8.0. This is similar to the findings of this study since a pH of 8 was found to be optimum for xylanase production. The inhibition in xylanase activities upon the addition of the metal salts or additives observed in this study could be attributed to the fact that proteins unfold in certain solvents, which disrupt its non-covalent interactions thus reducing its activity (Archana and Satyanarayana 1997; Podar and Reysenbach, 2006; Turner et al., 2007). A pH of 8 was found to be optimum for the activity of xylanase obtained from an alkalophilic Bacillus sp. Sam-3 (Shah et al., 1999). Pham et al. (1998) showed that the two xylanases produced by Bacillus polymyxa were not stable at $60^{\circ} \mathrm{C}$ even after $15 \mathrm{~min}$. Also, only 15 to $20 \%$ of residual activity of the crude xylanase from a Bacillus sp. was left at $60^{\circ} \mathrm{C}$ (Yang et al., 1995). This is in contrast to the present study because the crude enzyme extract from the organism retain up to $70 \%$ of its activity after $2 \mathrm{~h}$.

Shah et al. (1999) reported retention of approximately $75 \%$ xylanase at $60^{\circ} \mathrm{C}$ at the end of $2 \mathrm{~h}$ of incubation, while the enzyme was found unstable at $70^{\circ} \mathrm{C}$, with only $4 \%$ of the original activity retained after $45 \mathrm{~min}$. This is in contrast to the current study where the enzyme retained 56 to $98 \%$ of its activity after one hour at $70^{\circ} \mathrm{C}$ (Figure 4a). Similarly, Roy and Belaluddin (2004) showed that alkaline xylanases from Bacillus sp. isolated from an alkaline soda lake were stable at the temperature of 40 to $80^{\circ} \mathrm{C}$, with $60 \%$ loss in activity observed at $80 \%$ which is similar to the findings of this study.

In conclusion, for commercial production of xylanase enzymes, the focus should be on the utilization of agroresidual wastes along with development of efficient bioprocess strategies to obtain high enzyme titer (Biswas et al., 2010). The alternate substrates investigated in this study demonstrate a good potential for production of high titre of xylanase by the Bacillus strains. The enzyme also demonstrated high stability at a wide range of both alkaline conditions and high temperatures, thus making it a good candidate for use in Kraft pulp treatment. This could allow for direct enzymatic treatment of the alkaline pulp and avoids the cost incurring and time consuming steps of $\mathrm{pH}$ re-adjustment. Although sawdust differs in composition with respect to fibre structure and chemical composition, for example, contents of lignin, hemicelluloses, pectin and extractives, the present work has shown that sawdust could be considered as a promising material for enzyme production. Overall, the use of sawdust and digestive bran could provide a cheaper alternative for the large-scale production of xylanases, for various industrial applications, compared to oat-spelt and birchwood xylan currently being used in small scale experiments.

\section{REFERENCES}

Abdel-Sater MA, El-Said AHM (2001). Xylan-decomposing fungi and xylanolytic activity in agricultural and industrial wastes. Int Biodeterior. Biodegrad., 47: 15-21.

Álvarez P, Blanco C, Santamaría R, Grand M (2005). Lignocellulose/pitch based composites. Composites Part A., 36: 649657.

Anuradha P, Vijayalakshmi K, Prasanna ND, Sridevi K (2007). Production and properties of alkaline xylanases from Bacillus sp. Isolated from sugarcane fields. Curr. Sci., 92: 1283-1286.

Archana A, Satyanarayana T (1997). Xylanase production by thermophilic Bacillus licheniformis A99 in solid-state fermentation. Enzyme Microb. Technol., 21: 12-17.

Asther M, Meunier JC (1990). Increased thermostability of Bacillus licheniformis $\alpha$-amylase in the presence of various additives. Enzyme Microb. Technol., 12: 902-905.

Bachmann SL, McCarthy AJ (1991). Purification and cooperative activity of enzymes constituting the xylan degrading system of Thermomonospora fusca. Appl. Environ. Microbiol., 57: 2121-2130.

Bae HJ, Kim HJ, Kim YS (2008). Production of a recombinant xylanase in plants and its potential for pulp biobleaching applications. Bioresour. Technol., 99: 3513-3519.

Bailey M, Biely P, Poutanen K (1992). Interlaboratory testing of methods for assay of xylanase activity. J. Biotechnol., 23: 257-270.

Bataillon M, Cardinali APN, Castillon N, Duchiron F (2000). Purification and characterization of a moderately thermostable xylanase from Bacillus sp. strain SPS-0. Enzyme Microb. Technol., 26: 187-192.

Battan B, Sharma J, Dhiman SS, Kuhad RC (2007). Enhanced production of cellulase-free thermostable xylanase by Bacillus pumilus ASH and its potential application in paper industry. Enzyme Microb. Technol., 41: 733-739.

Batzias FA, Sidiras DK (2007). Simulation of dye adsorption by beech sawdust as affected by pH. J. Hazard Mater., 14: 668-679.

Beg QK, Bhushan B, Kapoor M, Hoondal GS (2000). Enhanced production of a thermostable xylanase from Streptomyces sp. QG-113 and its application in biobleaching of eucalyptus kraft pulp. Enzyme Microb. Technol., 27: 459-466.

Biely P (1985). Microbial xylanolytic system. Trends Biotechnol., 3: 286290.

Biswas R, Sahai V, Mishra S, Bisaria VS (2010). Bioprocess strategies for enhanced production of xylanase by Melanocarpus albomyces IITD3A on agro-residual extract. J. Biosci. Bioeng., doi:10.1016/j.jbiosc.2010.07.013.

Biswas SR, Jana SC, Mishra AK, Nanda G (1990). Production, purification, and characterization of xylanase from a hyperxylanolytic mutant of Aspergillus ochraceus. Biotechnol. Bioeng., 35: 244-251.

Bledzki AK, Gassan J (1999). Composites reinforced with cellulose based fibres. Prog. Polym. Sci., 24: 221-274.

Cacais AOG, De Paula Silveira FQ, Filho EXF (2001). Production of xylan degrading enzymes by a Trichoderma harzianum strain. Braz. J. Microbiol., 32: 141-143.

Camassola M, Dillon AJP (2009). Biological pretreatment of sugar cane bagasse for the production of cellulases and xylanases by Penicillium echinulatum. Ind. Crops Prod., 29: 642-647.

Chávez R, Bull P, Eyzaguirre J (2006). The xylanolytic enzyme system from the genus Penicillium. J. Biotechnol., 123: 413-433.

Contreras LM, Gómez J, Prieto J, Clemente-Jiménez JM, HerasVázquez FJL, Rodríguez-Vico F, Blanco FJ, Neira JL (2008). The family $52 \beta$-xylosidase from Geobacillus stearothermophilus is a dimer: Structural and biophysical characterization of a glycoside hydrolase. Biochim. Biophys. Acta, 1784: 1924-1934.

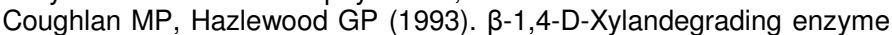
systems: Biochemistry, molecular biology and applications. Biotechnol. Appl. Biochem., 17: 259-289.

Duff SJB, Murrayh WD (1996). Bioconversion of forest products, industry waste cellulosics to fuel ethanol: A Review. Bioresour. Technol., 55: 31-33.

Esteghlalian AR, Kazaoka MM, Lowery BA, Varvak A, Hancock, B Woodward T, Turner JO, Blum DL, Weiner D, Hazlewood GP (2008). Prebleaching of softwood and hardwood pulps by a high performance 
xylanase belonging to a novel clade of glycosyl hydrolase family 11 Enzyme Microb. Technol., 42: 395-403.

Gessesse A (1998). Purification and properties of two thermostable alkaline xylanases from an alkaliphilic Bacillus sp. Appl. Environ. Microbiol., 64: 3533-3535.

Gessesse A, Mamo G (1999). High-level xylanase production by an alkaliphilic Bacillus sp. by using solid-state fermentation. Enzyme Microb. Technol., 25: 68-72.

Gilbert M, Breuil C, Saddler JN (1992). Characterization of the enzymes present in the cellulase system of Thielavia terrestris 255B. Bioresour. Technol., 39: 147-154.

Haltrich D, Nidetzky B, Kulbe KD, Steiner W, Župančič S (1996). Production of fungal xylanases. Bioresour. Technol., 58: 137-161.

Hidayah A, Mohd AH, Umi Kalsom MS, Norhafizah A, Farinazleen MG, Yoshihito S (2008). Production of bacterial endoglucanase from pretreated oil palm empty fruit bunch by Bacillus pumilus EB3. J. Biosci. Bioeng., 06: 231-236.

Joshi C, Khare SK (2010). Utilization of deoiled Jatropha curcas seed cake for production of xylanase from thermophilic Scytalidium thermophilum Bioresour. Technol., doi:10.1016/j.biortech.2010.08.070.

Kapoor M, Nair LM, Kuhad RC (2008). Cost-effective xylanase production from free and immobilized Bacillus pumilus strain MK001 and its application in saccharification of Prosopis juliflora. Biochem. Eng. J., 38: 88-97.

Liu M, Liu G (2008). Expression of recombinant Bacillus licheniformis xylanase A in Pichia pastoris and xylooligosaccharides released from xylans by it. Protein Expression Purif., 57: 101-107.

Maheshwari R, Bharadwaj G, Bhat MK (2000). Thermophilic fungi: Their physiology and enzymes. Microbiol. Mol. Biol. Rev., 64: 461-488.

Mamo G, Hatti-Kaul R, Mattiasson B (2006). A thermostable alkaline active endo-B-1-4-xylanase from Bacillus halodurans S7: Purification and characterization. Enzyme Microb. Technol., 39: 1492-1498.

Miller $L$ (1959). Use of dinitrosalicylic acid reagent for determination of reducing sugar. Anal. Chem., 31: 426-428.

Nawel B, Said B, Estelle C, Hakim H, Duchiron F (2010). Production and partial characterization of xylanase produced by Jonesia denitrificans isolated in Algerian soil. Process Biochem. doi:10.1016/j.procbio.2010.10.003.

Ninawe S, Kuhad RC (2006). Bleaching of wheat straw-rich soda pulp with xylanase from a thermoalkalophilic Streptomyces cyaneus SN32. Bioresour. Technol., 97: 2291-2295.

Pham PL, Taillandier P, Delmas M, Strehaiano P (1998). Production of xylanases by Bacillus polymyxa using lignocellulosic wastes. Ind. Crops Prod., 7: 195-203.

Pinaga F, Pena JL, Vallés S (1993). Xylanase production by $B$. polymyxa. J. Chem. Technol. Biotechnol., 57: 327-333.
Podar M, Reysenbach A (2006). New opportunities revealed by biotechnological explorations of extremophiles. Curr. Opin. Biotechnol., 17: 250-255.

Prescott M, Harley JP, Klein DA (1996). Microbiology $3^{\text {rd }}$ ed., W. M. C. Brow Publishers, New York, p. 176.

Ramesh M, Lonsame BK (1989). Solid state fermentation for production of higher titers of thermostable alpha-amylase with two peaks for $\mathrm{pH}$ optimum by Bacillus licheniformis M27. Biotechnol. Lett., 11: 49-52.

Roy N, Belaluddin M (2004). Production and characterization of alkaline xylanases from Bacillus sp. isolated from an alkaline soda lake. J. Biol. Sci., 7: 777-781.

Sa'-Pereira P, Costa-Ferreira M, Aires-Barros MR (2002). Enzymatic properties of a neutral endo-1,3(4)- $\beta$-xylanase Xyl II from Bacillus subtilis. J. Biotechnol., 94: 265-275.

Shah AK, Sidid SS, Ahmad A, Rele MV (1999). Treatment of bagasse pulp with cellulase-free xylanases from an alkalophilic Bacillus $s p$. Sam-3. Bioresour. Technol., 68: 133-140.

Srinivasan MC, Rele MV (1999). Microbial xylanases for pulp and paper industry. Curr. Sci., 77: 137-42.

Subramaniyan S, Prema $P$ (2000). Cellulase free xylanases from Bacillus and other microorganisms. FEMS Microbiol. Lett., 183: 1-7.

Sunna A, Antranikian G (1997). Xylanolytic enzymes from fungi and bacteria. Crit. Rev. Biotechnol., 17: 39-67.

Taiz L, Hongman WA (1976). Production of cell wall hydrolyzing enzymes by barley aleurone layer in response to gibberellic acid. Plant Physiol., 58: 380-386.

Techapun C, Poosaran N, Watanabe M, Sasaki K (2003). Thermostable and alkaline-tolerant microbial cellulase free xylanases produced from agricultural wastes and the properties required for use in pulp bleaching bioprocess: A review. Process Biochem. 38: 1237-1340.

Turner P, Mamo G, Karlsson EN (2007). Potential and utilization of thermophiles and thermostable enzymes in biorefining. Microb. Cell Fact. 6:9doi:10.1186/1475-2859.

Viikari L, Kantelinen A, Sundquist J, Linko M (1994). Xylanases in bleaching: from an idea to the industry. FEMS Microbiol. Rev., 13: 335-350.

Wong KKY, Tan LUL, JN Saddler (1988). Multiplicity of 3-1,4-xylanase in microorganisms: functions and applications. Microbiol. Rev., 52: 305-317.

Yang VW, Zhuang Z, Elegir G, Jeffries TW (1995). Alkaline-active xylanase produced by an alkaliphilic Bacillus $s p$ isolated from Kraft pulp. J. Ind. Microbiol., 15: 434-441. 